\title{
Toxicity Assessment of an Aqueous Extract of the Stem Bark of Spondias mombin (Anacardiaceae) in wistar albino rats
}

\author{
Gbogbo Moussa ${ }^{1,2 *}$, Toure Alassane ${ }^{3}$, Kouadio YaoEmile ${ }^{2}$, Oussou N'guessan Jean- \\ Baptiste $^{2}$, Kone Mama ${ }^{2}$, Diby Yao Bernard ${ }^{2}$ and Yapo AngouéPaul ${ }^{2}$ \\ ${ }^{1}$ Department of Biochemistry-Microbiology, Jean Lorougnon-Guédé University; \\ BP 150 Daloa \\ ${ }^{2}$ Laboratory of Physiology, Pharmacology and Pharmacopoeia, Nangui Abrogoua University, \\ 01 BP 801 Abidjan 01 \\ ${ }^{3}$ CIRDES, Bobo-Dioulasso, 01 BP 454 Bobo-Dioulasso 01 \\ *Corresponding author
}

\section{A B S T R A C T}

\begin{tabular}{|l|}
\hline K e y w o r d s \\
$\begin{array}{l}\text { Spondias mombin, } \\
\text { aqueous extract, blood } \\
\text { smear, hemolysis, } \\
\text { histological sections, } \\
\text { rat }\end{array}$ \\
\hline Article Info \\
\hline $\begin{array}{l}\text { Accepted: } \\
\text { 30 January } 2018 \\
\text { Available Online: } \\
\text { 10 February } 2018\end{array}$ \\
\hline
\end{tabular}

\section{Introduction}

Plants have been used for therapeutic purposes for a long time. This practice continues in many parts of the world because of its biomedical benefits and cultural beliefs (WHO, 2002). The remoteness, the scarcity or lack of health centers in villages, the unavailability and often the high cost of
The total aqueous extract of the stem bark of Spondias mombin L. (Anacardiaceae) is involved in the treatment of several pathologies including digestive disorders in Côte d'Ivoire. To verify its safety, three doses $(250,500$ and $1000 \mathrm{mg} / \mathrm{kg}$ body weight) of Spondias mombin extractis administered daily orally to three groups of albino Wistar rats for 28 days. The control group received distilled water. Blood sample is taken to evaluate the rate of erythrocytes, hemoglobin and hematocrit of all experimental rats. A blood smear and hemolysis tests were performed to determine the effect of the extract on the quality of erythrocytes. After 28 days, a histological study was also performed on the liver and kidneys of all rats. The results of this work indicated a significant decrease in erythrocyte parameters studied. On blood smears, hypochromia, target red blood cells, and schizocytes were observed in the rats treated with 500 and $1000 \mathrm{mg} / \mathrm{kg} \mathrm{b}$.w. In vitro study on rat red blood cells indicated a progressive increase in hemolysis percentages over time in tubes with different concentrations of extract. Histological study of the liver of the kidneys revealed steatosis, cell death by apoptosis, necrosis and calcification of nephron tubules. 
preparation and evaluation. For this purpose, WHO (2002) recommends the evaluation of the quality, efficacy and safety of medicinal plants.

In this context, Spondias mombin L. (Anacardiaceae), which is used for the treatment of diarrhea in Ivory Coast, has been the subject of this research. Spondias mombin is a tree of about 12 to $25 \mathrm{~m}$ high with a trunk covered with thick, rough bark (Adjanohoun and Aké-Assi, 1979). The leaves are alternate, imparipinnate, and made of 5 to 8 pairs of opposite or alternate leaflets. The fruits are ellipsoid or ovoid drupes, yellow when get matured with astringent flesh, sweet and more or less acidulous.

Many scientific works have been done on the $S$. mombinorgans. For instance, Corthout et al., (1994) demonstrated that the leaves and stem bark of this plant exhibit antibacterial activity against Bacillus cereus, Streptococcus pygenes and Mycobacterium fortuitum. Spondias mombin also has a very clear molluscicidal property due to the phenolic acid isolated from the ethanolic extract of the leaves. Antiplasmodial activity was reported in 2004 by Caraballo et al., In 2006, Ayoka et al., demonstrated the sedative, antiepileptic and antipsychotic effects of Spondias mombin in mice and rats.

Diby et al., 2012, showed that the total aqueous extract of $S$. mombin stem bark causes a decrease in rhythmic contractions as well as a modification of the basic tone of the rabbit isolated duodenum at concentration ranging from 397 to $794 \mu \mathrm{g} / \mathrm{ml}$. Its effective concentration $50 \%$ (EC50) is $625 \mu \mathrm{g} / \mathrm{ml}$ with concentration-dependent myorelaxant effect. A previous study showed that the total aqueous extract of Spondias mombin stem bark reduced food and water consumption, an increase of body weight and increases serum levels of Glutamate-Pyruvate transaminases, urea and creatinine in rats treated with 500 and $1000 \mathrm{mg} / \mathrm{kg}$ b.w. of this extract (Gbogbo et al., 2014).

The present study aims at elucidating the toxicity effects of the total aqueous extract of S. mombin stem bark on rats' blood cells, liver and kidneys tissues.

\section{Materials and Methods}

The stem bark of Spondias mombin was harvested in December 2011 in Kokumbo, in the department of Toumodi (Côte d'Ivoire), located at about $200 \mathrm{~km}$ far from Abidjan. The identification of this plant was done and confirmed by researcher at the National floristic Center of Felix Houphouet Boigny University (Abidjan). The voucher number was 1596, June $2^{\text {nd }} 1952$ of Côte d'IvoireNational Herbarium harvested in N'zida (GrandLahou).

Ratus norvegicus rats of Wistar strain aging about six weeks old and weighing between 100 and $104 \mathrm{~g}$ were used for the experiments. All animals are exposed to a temperature of 25 ${ }^{\circ} \mathrm{C} \pm 2$ and $12 \mathrm{~h}$ dark/light cycle. Rats were fed with IVOGRAIN ${ }^{\circledR}$ granules and given water ad libithum. The experimental protocol and the animal handling procedures were conducted according to the guidelines of the ethics committee of Nangui Abrogoua University (Côte d'Ivoire).

The stem barks of S. mombin were dried in a laboratory room at $25 \pm 2{ }^{\circ} \mathrm{C}$ for two weeks and crushed with a grinder (Mark RETSCH, type SM 100, Germany). Fifty grams (50 g) of the leaf powder were macerated in $1 \mathrm{~L}$ of distilled water using a magnetic stirring for 24 hours at room temperature $(25 \pm 2 \circ \mathrm{C})$ (Guédé-Guina et al., 1993). The macerate obtained were filtered on hydrophilic cotton and Watman $\mathrm{n}^{\circ} 1$ paper. The filtrate is then concentrated under reduced pressure at $60{ }^{\circ} \mathrm{C}$ 
using a Buch i R110 type MKE 6540/2 rotary evaporator. The concentrated filtrate were dried in an oven at $45{ }^{\circ} \mathrm{C}$ for 48 hours. The extract powder obtained were weighed and stored in a freezer at $-5{ }^{\circ} \mathrm{C}$ until ready for use.

Subacute toxicity study were based on OECD test Guideline 407 (OECD, 1995) which consists in administering four doses of drugs, daily, by oral route to four different groups of animals for 28 days. Forty (40) rats were randomly shared in four batches of 10 animals including three test groups (B, C and D) and one control group (A). Each batch contains five female rats and five male. Three (03) doses were prepared according to those used in the work of Gbogbo et al., 2014. The doses of 250,500 and $1000 \mathrm{mg} / \mathrm{kg} \mathrm{b.w.} \mathrm{were}$ respectively administered to groups $\mathrm{B}, \mathrm{C}$ and D. The control group received distilled water. Before administration of the extract, animals of each batch were individually marked and weighed. They received by gavage, a volume of solution of $2 \mathrm{ml} / 100 \mathrm{~g}$ of body weight.

Blood samples were collected in a tube containing ethylene diamine tetraacetic acid (EDTA) on days 7, 14, 21 and 28 using the blood collection technique described by Kraus, (1980). Blood counts and blood smears, fixed and stained with May-grunwald Giema were performed to assess the quality and quantity of red blood cells.

The assessment of the hemolytic effect of the aqueous extract of Spondias mombin stem bark was performed on an erythrocyte suspension of rat blood. Blood samples was thus collected in tubes containing EDTA and then centrifuged at $2400 \mathrm{rpm}$ for 15 minutes. Plasma were then discarded. The erythrocytecontaining pellet was washed three times in phosphate buffered saline solution according to the method of Guo-Xiang and Zai-Qun (2008). Four (04) concentration levels (Negative control $=0 \mathrm{mg} / \mathrm{ml}, C_{1}=3.12$ $\mathrm{mg} / \mathrm{ml}, \mathrm{C}_{2}=6.25 \mathrm{mg} / \mathrm{ml}$ and $\mathrm{C}_{3}=12.50$ $\mathrm{mg} / \mathrm{ml}$ ) were made for the study. The different concentrations of extracts were prepared in phosphate buffer solution (PBS). Under the same experimental condition, a total hemolysis tube containing erythrocyte suspension and distilled water were prepared. The absorbance (A) of each tube were recorded using a spectrophotometer at $548 \mathrm{~nm}$ at different times $(0,15,30$ and $60 \mathrm{~min})$. The hemolysis rate were calculated using the following formula.

$\frac{\text { Hemolysis }}{\text { A samples-A control }}$ A total hemolysis-A control $\times 100$

At the end of the experiments, the liver and kidneys of the rats were removed and weighed. The relative organs-body weight were calculated using the formula described by Yakuba et al., 2008.

Relative organs body weight $(\%)=$ Organ weight (g)

$\overline{\text { Animal weight }(g) \text { on the day of sacrifice }} \times 100$

The organs were then fixed in $10 \%$ formaldehyde in order to perform histological sections stained with hematoxylin-eosin using the paraffin embedding technique as described by Hould, 1984. On histological sections, necrosis, steatosis, congestion, hypertrophy and calcification of rats' liver and kidneys were assessed.

The statistical study was performed using Xlstat-pro 7.1 statistical analysis software. The results were analyzed using one-way analysis of variance (ANOVA) followed by multiple comparison tests associated with Dunnett's post hoc tests.

Data are presented as means \pm SEM. Differences were considered statistically significant at $p<0.05$. 


\section{Results and Discussion}

Effect of the extract on erythrocytes, hemoglobin and hematocrit

The administration of the total aqueous extract of Spondias mombin stem bark causes a significant decrease $(p<0.05)$ of red blood cell counts throughout the study in rats treated with 500 and $1000 \mathrm{mg} / \mathrm{kg}$ b.w. compared to the controls whereas the dose of $250 \mathrm{mg} / \mathrm{kg}$ b.w. did not (Figure 1). Concerning the evolution of the hemoglobin level, a significant $\quad(p<0.05, \quad p<0.01) \quad$ decrease reflecting anemia was observed in all the groups respectively treated with 250, 500 and $1000 \mathrm{mg} / \mathrm{kg}$ b.w. of Spondias mombin throughout the study (Figure 2). Hematocrit was significantly lowered $(p<0.05)$ in rats' treated with $250 \mathrm{mg} / \mathrm{kg} \mathrm{b.w}$. of the extract when compared to controls and also more significantly lowered in those treated with 500 and $1000 \mathrm{mg} / \mathrm{kg}$ b.w.(Figure 3).

\section{Blood smear}

The different disturbances of erythrocyte parameters were also observed in the blood smear. Indeed, the different smears revealed the presence of abnormalities related to the color and shape of red blood cells (Figure 4). Figure 4A shows a normal rat blood smear stained with May-grunwald Giemsa. The target red blood cells associated with hypochromia were significantly $(p<0.05)$ observed in rats treated with $1000 \mathrm{mg} / \mathrm{kg}$ b.w. of Spondias mombin extract compared to the control group (Figure 4B). Schizocytes that reflect pattern abnormalities were also significantly $(p<0.05)$ observed in the extracttreated groups (500 and $1000 \mathrm{mg} / \mathrm{kg}$ b.w.)

\section{Hemolysis test}

In general, the percentage of hemolysis were gradually increased over time in all the tubes containing the different concentrations of extracts compared to the control tube (Figure 5). At the beginning $(\mathrm{T}=0 \mathrm{~min})$, no significant variation in the rate of hemolysis was observed in all the tubes. In contrast, at times $\mathrm{T}_{2}$ and $\mathrm{T}_{3}$, the aqueous extract of Spondias mombinat the concentration $\mathrm{C}_{1}=$ $3.12 \mathrm{mg} / \mathrm{ml}$ significantly $(p<0.05)$ caused nearly $50 \%$ of cells hemolysis compared to that observed in the control blood sample. At time $\mathrm{T}=60 \mathrm{~min}$, the percentage of hemolysis is about $100 \%$ when blood sample is mixed with the concentration of extract mentioned above. $6.25 \mathrm{mg} / \mathrm{ml}$ of Spondias mombin extract $\left(\mathrm{C}_{2}\right)$ caused slight increases in hemolysis proportions over the time but these were not statistically significant $(p>0.05)$ compared to the levels observed in the control group. The proportions of hemolysis increased significantly $(\mathrm{p}<0.05)$ over time in the tubes containing $12.5 \mathrm{mg} / \mathrm{ml}$ of $S$. mombin extract $\left(\mathrm{C}_{3}\right)$.

\section{Anatomohistological study}

Anatomohistological study conducted after a period of 28 days revealed, results did not show any significant change in the relative liver and kidney weights of rats' treated with the total aqueous extract of Spondias mombin stem bark compared to that of the control group (Table 1).Histological sections revealed normal liver sections of rats treated with distilled water (Figure 6A). Rat's treatment with 500 and $1000 \mathrm{mg} / \mathrm{kg}$ b.w. of $S$. mombin extract induced steatosis (Figure 6B) and apoptosis (Figure 6C) respectively in liver. Thus, 30\% of the liver sections of the rats dosed at $1000 \mathrm{mg} / \mathrm{kg}$ b.w. showed apoptosis. Regarding the renal sections, all animals in the control group and those receiving orally 250 $\mathrm{mg} / \mathrm{kg}$ b.w. of the extract had a normal kidney section (Figure 6D). In contrast, those of 500 and $1000 \mathrm{mg} / \mathrm{kg}$ b.w. groups revealed necrosis and calcification in kidney sections (Figure $6 \mathrm{E})$. 
Fig.1 Effects of Spondias mombin total aqueous extract on erythrocytes over time

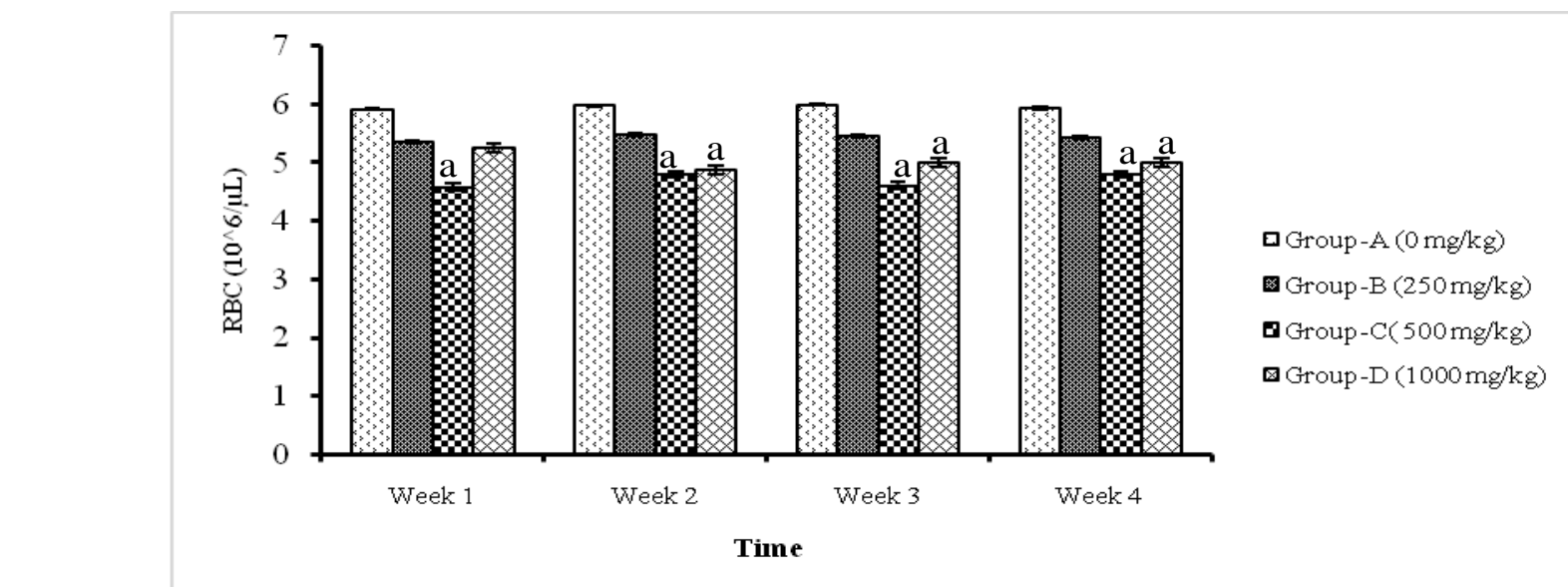

$\mathrm{a}=\mathrm{p}<0.05$

Fig.2 Effects of Spondias mombin total aqueous extract on hemoglobin level over time

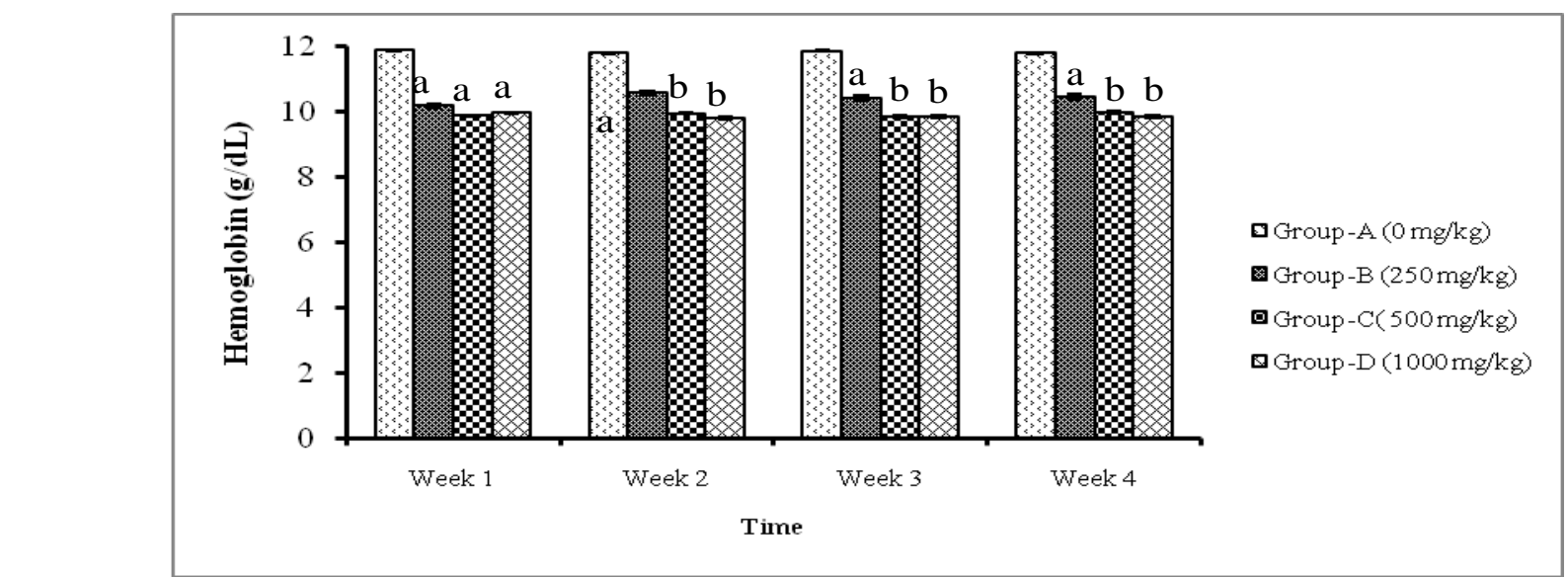

$\mathrm{a}=p<0.05 ; \mathrm{b}=p<0.01$

Fig.3 Effects of Spondias mombin total aqueous extract on hematocrit level over time

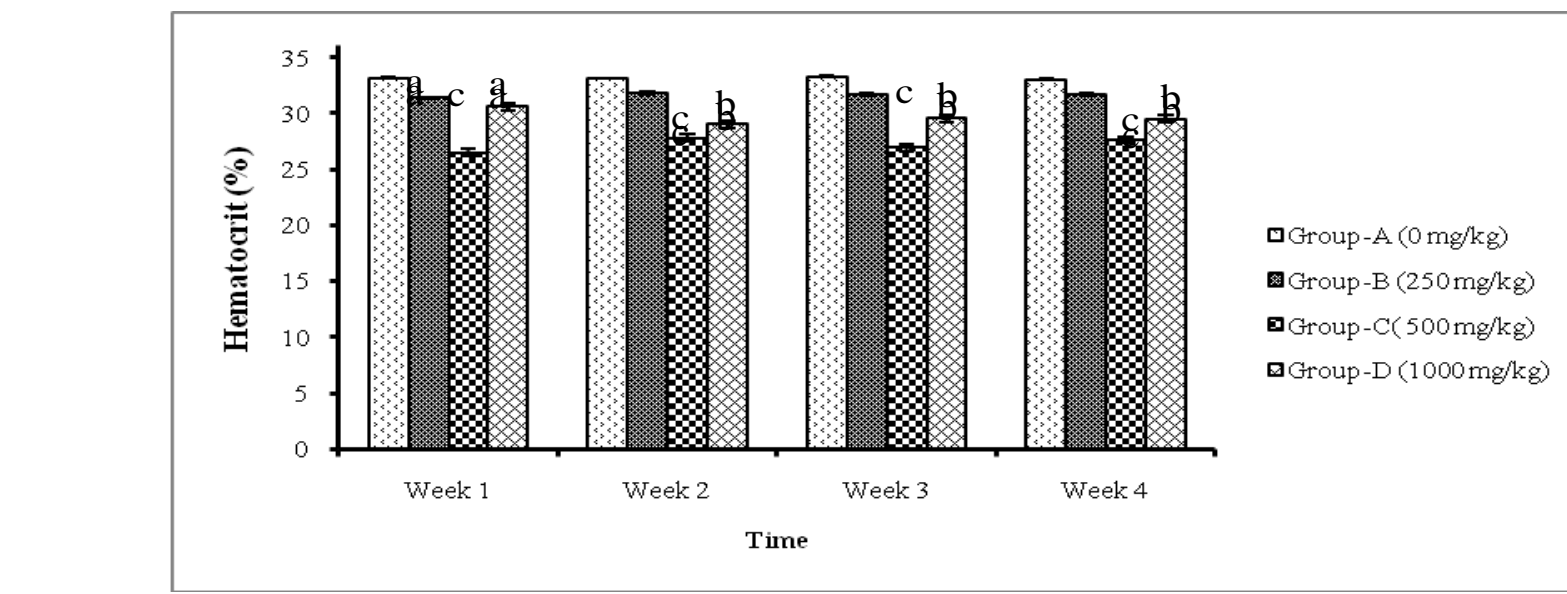

$\mathrm{a}=p<0.05 ; \mathrm{b}=p<0.01 ; \mathrm{c}=p<0.001$ 
Fig.4 Blood smear of May-Grünwald-Giemsa stained rat blood (MGG)
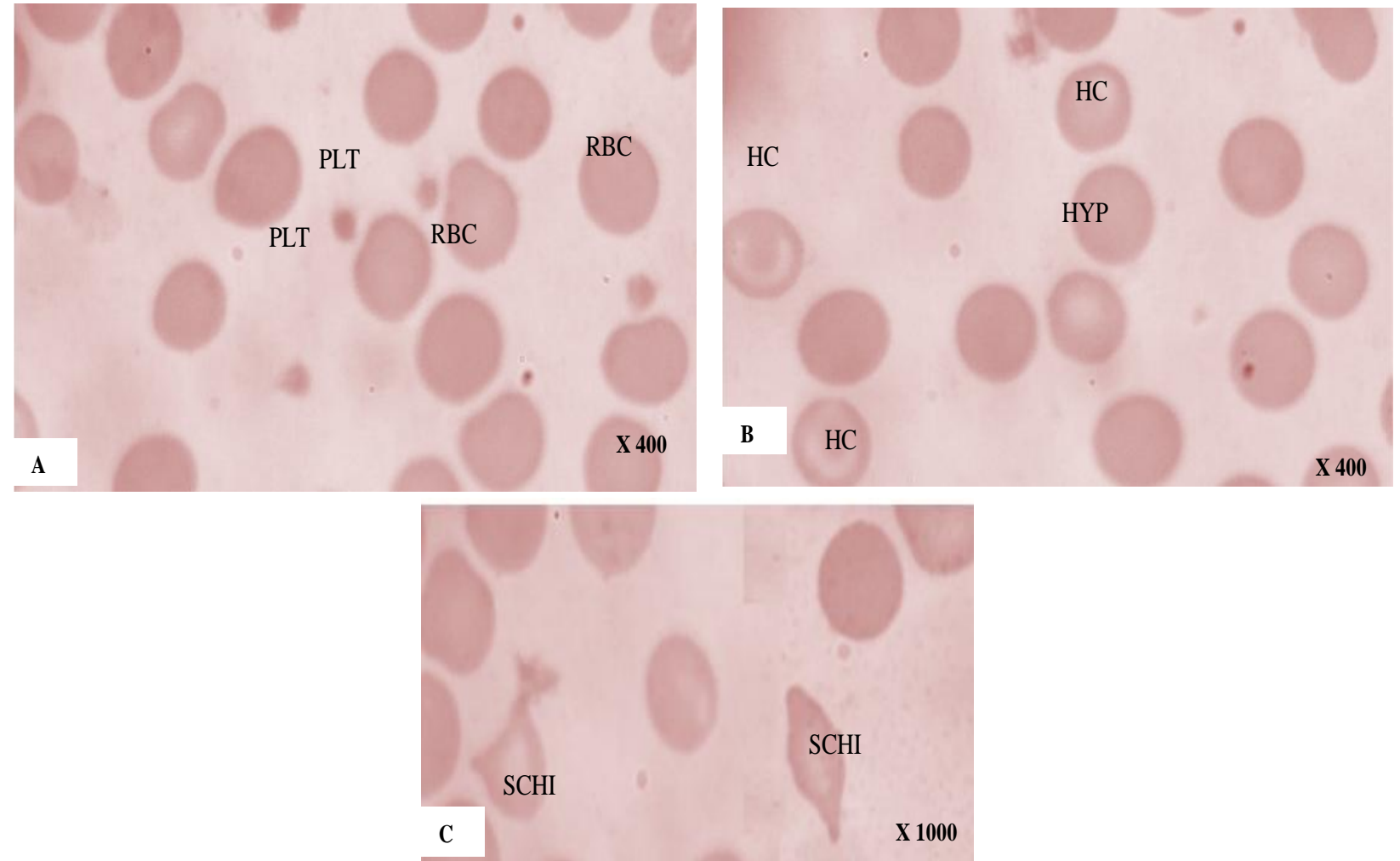

Magnification $(\times 400$ and $\times 1000)$. A: Normal red blood cells of the rats control group by their size, color and shape. RBC: Red blood cell; PLT: Platelet. B: Target red blood cells and hypochromic red blood cells in the group of rats treated with $500 \mathrm{mg} / \mathrm{kg}$ b.w. of Spondias mombin extract, HC: Hematoma target; Hyp: hypochromia. C: Schizocytes or of red blood cells fragments in the group of rats treated with $1000 \mathrm{mg} / \mathrm{kg}$ b.w of Spondias mombin extract. SCHI: Schizocyte.

Fig.5 Hemolysis of rat's red blood cells mixed with different concentrations of aqueous extract of Spondias mombin

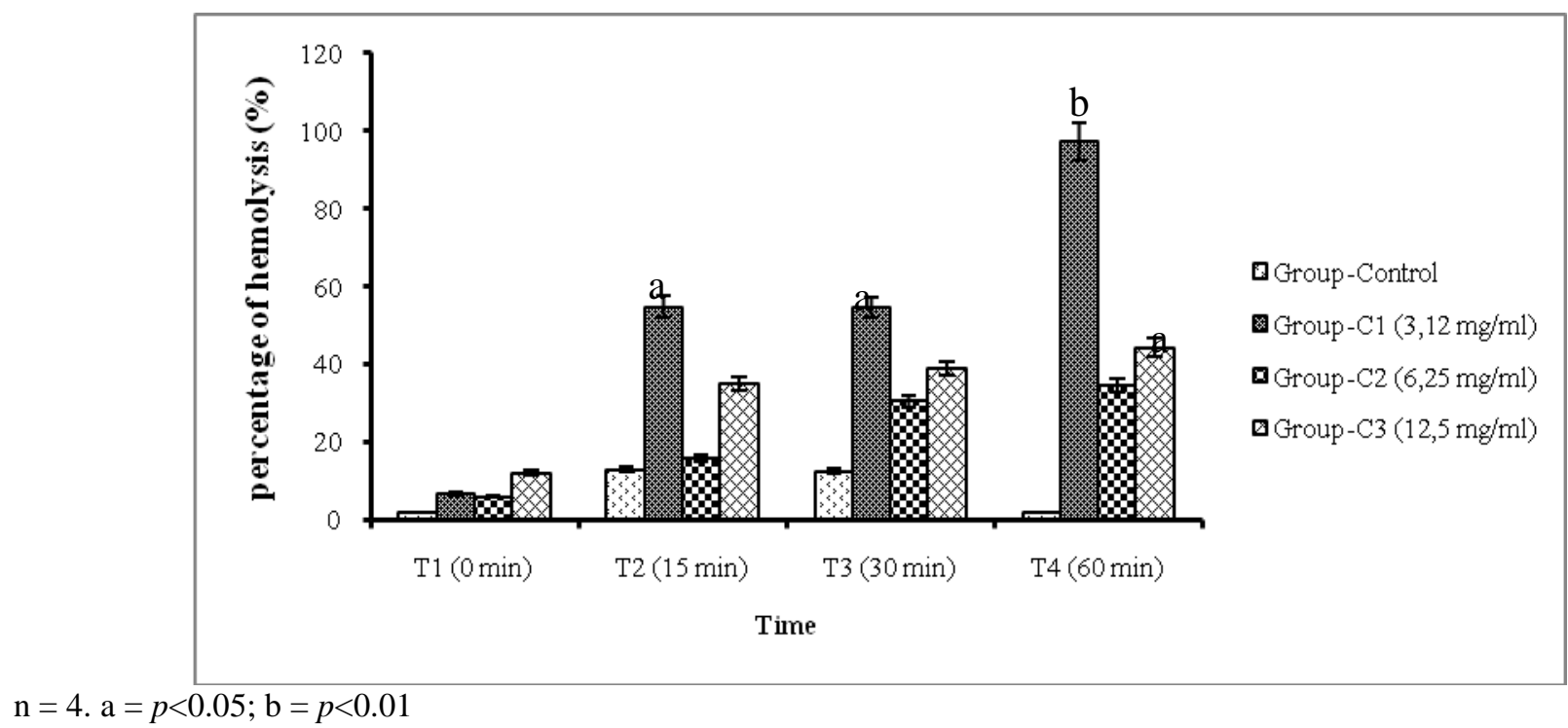


Fig.6 Photomicrographs liver and kidney sections of rat treated with the total aqueous extract of Spondias mombin stem bark
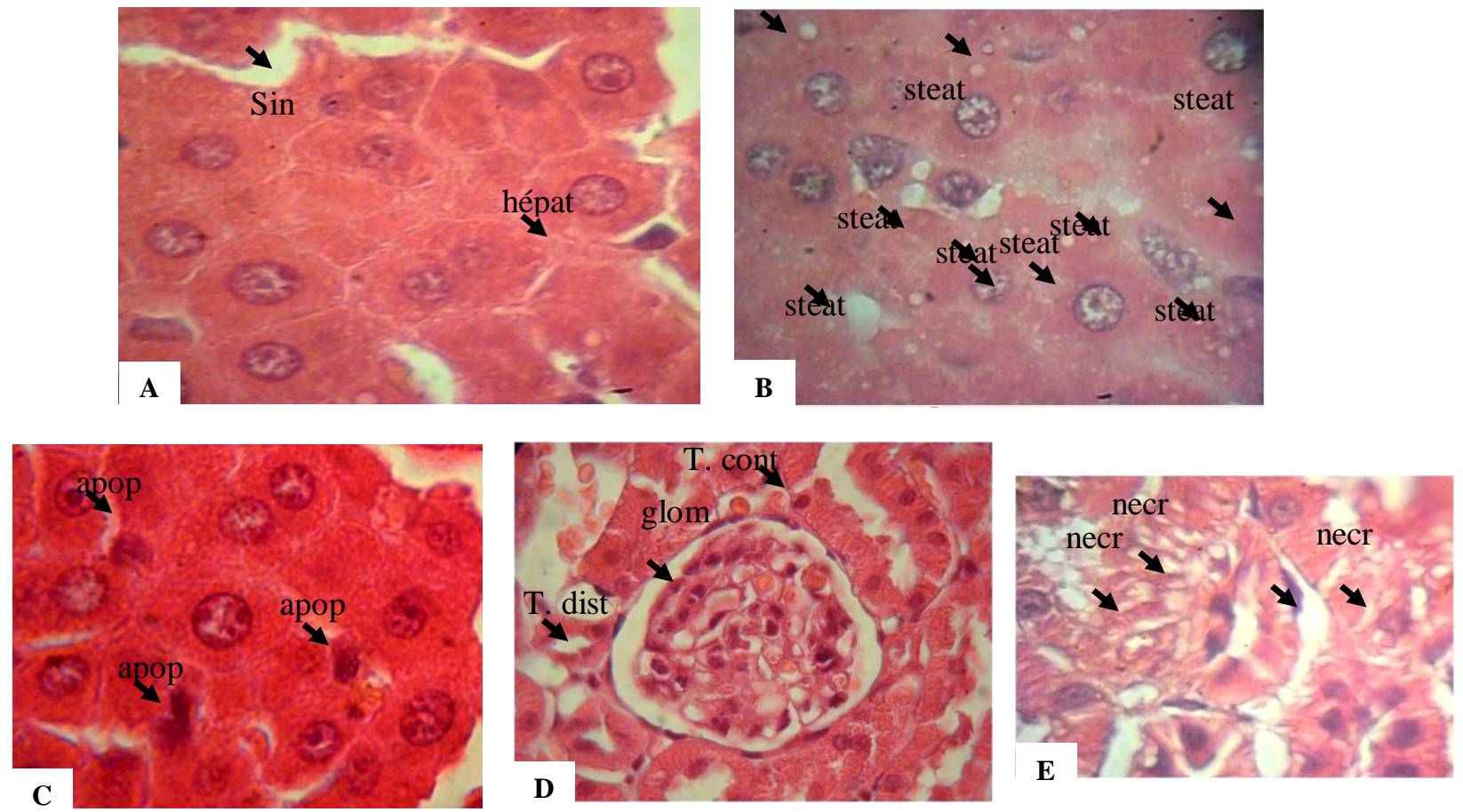

Magnification (x 1000). Stained: Hematoxylin-Eosin. A: normal appearance of hepatic architecture; B: Steatosis liver section in rats treated with the extract $(500 \mathrm{mg} / \mathrm{kg} \mathrm{b.w})$; C: Liver section with apoptotic cells in rats treated with $1000 \mathrm{mg} / \mathrm{kg}$ b.w. of Spondias mombin extract; D: normal appearance of rat renal architecture; E: renal necrosis and calcification in rats treated with the extract at $500 \mathrm{mg} / \mathrm{kg}$ b.w. Steat: steatosis; apop: apoptosis; necr: necrosis.

Table.1 Effects of the total aqueous extract of Spondias mombin on relative liver and kidneys of rats

\begin{tabular}{|c|}
\hline Doses $(\mathrm{mg} / \mathrm{kgb} . \mathbf{w})$. \\
\hline 0 \\
\hline 250 \\
\hline $\mathbf{5 0 0}$ \\
\hline 1000 \\
\hline
\end{tabular}

\begin{tabular}{|c|c|}
\hline Liver & kidneys \\
\hline $3.87 \pm 0.24^{\mathrm{ns}}$ & $0.79 \pm 0.03^{\mathrm{ns}}$ \\
\hline $4.12 \pm 0.23^{\mathrm{ns}}$ & $0.77 \pm 0.01^{\mathrm{ns}}$ \\
\hline $4.40 \pm 0.41^{\mathrm{ns}}$ & $0.78 \pm 0.03^{\mathrm{ns}}$ \\
\hline $4.19 \pm 0.05^{\mathrm{ns}}$ & $0.76 \pm 0.05^{\mathrm{ns}}$ \\
\hline
\end{tabular}

ns: non significative

Blood cells are among the organs targeted by drugs. Thus, any change in hematological parameters has a predictive value for human intoxication when data are from studies conducted in animal (Olson et al., 2000).

In this research work, red blood cells and erythrocyte parameters were significantly decreased by the total aqueous extract of
Spondias mombin stem bark. The effects on blood parameters could be justified by the presence of certain compounds having hemolytic properties of the extract of the extract. Indeed, Diby et al., 2012, demonstrated the presence of saponin in the total aqueous extract of the stem bark of $S$. mombin. According to Arias et al., 2010, saponins induce a decrease in red blood cells 
production and/or lead to their destruction. The high proportion of red blood cells' fragments or schizocytes, especially groups of rats treated with 500 and $1000 \mathrm{mg} / \mathrm{kg}$ b.w. ofSpondias mombin extract demonstrated hemolytic properties of this extract when it is taken at a high dose. Our results are similar to those obtained by Gomé et al., 2011 who reported a decrease in the number of red blood cells in rats treated with the aqueous extract of Passiflora foetida Linn. (Passifloraceae) at a dose of $1200 \mathrm{mg} / \mathrm{kg}$ b.w. In addition, anemia was found in all treated rats. It is known that the main role of hemoglobins contained in erythrocytes cells is to carry oxygen and carbon dioxide (Silbernagl \& Despopoulos, 2000). Thus, a significant decrease in these erythrocyte proteins could be showed the harmful effects of the total aqueous extract of $S$. mombin on red blood cells. Anemia induces a deficit of iron which causes inefficient erythropoiesis leading to erythrocytes fragility and their fragmentation (Fossat \& Roméo, 2006). The decrease in hematocrit level and the occurrence of hypochromia are characteristic of anemia. According to Fenneteau et al., 2006 the target red blood cells result of an increase in the ratio of the erythrocyte surface area to the volume of the erythrocyte, as a consequence of a decrease in the amount of hemoglobin.

The in vitro study indicated a progressive increase in hemolysis rate over time. These evolutions reached $97.25,34.36$ and $44.33 \%$ respectively for concentrations of $3.12,6.25$ and $12.5 \mathrm{mg} / \mathrm{ml}$ of the extract after 60 minutes. Like the in vivo tests, the aqueous extract of S. mombin stem bark caused in vitro adverse effects on red blood cells. Our results are similar to those of Elalaoui (2014) that showed a hemolysis rate of about $90 \%$ after incubation of isolated red blood cells in PBS with ahydro-alcoholic crude extracts of Nigella sativa seeds. According to Gros et al.,
1996, the deoxygenation of hemoglobin and its oxidation to methemoglobin can generate oxygen radicals that are normally eliminated by the intrinsic antioxidant systems of erythrocytes. Subsequently, oxyradicals cause oxidative attacks on the membranes and thus cause hemolysis.

Regarding the relative liver and kidneys body weights; the results found in our studies indicated a non-significant change of the organs of rats treated with $S$. mombin extract $(250,500$ and $1000 \mathrm{mg} / \mathrm{kg}$ b.w.) compared to those of the controls. Our results are similar to those obtained by Ansah et al., 2011. In fact, these researchers showed that the repeated administration for two weeks of the leaves aqueous extract of Alchornea cordifolia (Schumach and Thonn) Müll. Arg. (Euphorbiaceace), at doses ranging from 500 to $2000 \mathrm{mg} / \mathrm{kg} \mathrm{b}$.w. to rats does not influence the relative organs body.

Histological examination of the liver showed steatosis in liver sections of rats treated with 500 and $1000 \mathrm{mg} / \mathrm{kg} \mathrm{b.w}$. There is evidence that steatosis is due either to abnormal oxidation of fatty acids in case of mitochondria damaged, or deterioration in the systemic transport of fatty acids via secretion of very low density proteins in case of malnutrition, or to the action of toxins (Fabbrini et al., 2010). Pessayre (1995) reports that during a drug poisoning, $\beta$ oxidation is inhibited leading to accumulation of fatty acids in the cytosol as emulsified triglycerides causing steatosis.

Our results are different to those of Hayelom et al., 2012 that showed that repeated administration of 100,400 and $1630 \mathrm{mg} / \mathrm{kg}$ b.w. of the roots methanolic extract of Clerodendrum myricoides (Verbenaceae) to Swiss mice for 44 days causes inflammation and hydropic degeneration of hepatocytes but not the occurrence of steatosis. 
In addition to steatosis, the total aqueous extract of Spondias mombin caused apoptosis. The observation of cell deaths during the study confirms the elevation of serum activity of transaminases like ALAT as previously shown by Gbogbo et al., (2014). In fact, the increase of serum transaminases level is explained by the fact that during cell deaths, there is destruction of the hepatic parenchyma or an increase in the hepatocytes membrane permeability, thus leads to the flow of these enzymes into blood vessels circulation and therefore increase their levels in serum (Adeneye et al., 2006). In contrast to necrosis, several authors agree that apoptosis has a very important physiological role in normal cell turnover in adult tissues (Payne et al., 1995, Scoazec, 1997). However, observation of apoptotic cells in group of rats treated with $1000 \mathrm{mg} / \mathrm{kg}$ b.w. of $S$. mombin may be indicative of cellular aggression whose mechanism remains unclear. Our results corroborate those found by Asuquo et al., 2012. They demonstrated the toxicity of the ethanolic extract of $S$. mombin leaves. In fact, they observed a disturbance in the structure of the seminiferous tube cells, cellular necrosis, a significant reduction of the seminal fluid of the rats at $500 \mathrm{mg} / \mathrm{kg} \mathrm{b.w}$. of the extract.

Results of the histological assessment of the aqueous extract of S. mombinon treated rats' kidneys caused calcification and necrosis. The effect of the total aqueous extract of $S$. mombin stem bark is not comparable to that of the aqueous leaf extract of Vernonia bipontini Vatke (Asteraceae). Indeed, Mebratu et al., (2013) have shown that the administration of the aqueous extract of Vernonia bipontini leaves at 400 and 800 $\mathrm{mg} / \mathrm{kg} \mathrm{b.w}$. to mice does not cause any lesionof kidneys.

In conclusion, Spondias mombin stem bark extract caused decreases in the rate of red blood cells, hemoglobin levels and hematocrit levels. Hematological disturbances were also observed in rats' blood smears by hypochromia, target red blood cells and schizocytes. A hemolytic effect test revealed a high proportion of hemolysis. Though no significant change in the relative organs body weights was found, steatosis and apoptosis have been observed in the liver and necrosis and calcification in kidney sections.

Therefore the total aqueous extract of $S$. mombin stem bark may be harmful in albino wistar rats when administered over a 28-day period.

\section{References}

Adeneye, A. A., Ajagbonna, O. P., Adeleke T. I., Bello S.O. 2006. Preliminary toxicity and phytochemical studies of the stem bark aqueous extract of Musanga cecropioides in rats. $J$. Ethnopharmacol., 105: 374-379.

Adjanohoun, E.J., Aké Assi, L., Floret, J.J., Guinko, S., Koumaré, M., Ahyi, A.M.R., Raynal, J. 1979.Médicine traditionnelle et pharmacopée, contribution aux études ethnobotaniques et floristiques au Mali. Agence de Coopération Culturelle et Technique (ACCT), Paris ; 221-224.

Ansah, C., Oppong, E., Woode, E. 2011.Subacute oral toxicity assessment of Alchornea cordifolia (Schumach and Thonn) Müll Arg (Euphorbiaceae) extract in Rats. Trop $J$ Pharm Res., 10(5): 587.

Arias, M., Quijano, J.C., Haridas, V., Gutterman, J.U., Lemeshko, V.V. 2010. Red blood cell permeabilization by hypotonic treatments, saponin, and anticancer avicins. Biochimica et Biophysica Acta, 1798:1189-1196.

Asuquo, R.O., Ekanem, B. T., Udoh, B.P., Eluwa, A. M. 2012.Histomorphological study of the anti-fertility effect of 
Spondias mombin L. in adult male rats. J. of Pharm. And boil. Sc., 3:29-34.

Ayoka, A.O., Akomolafe, R.O., Iwalewa, E.O., Ukponmwan, O.E. 2006. Studies on the anxiolytic effect of Spondias mombin L. (Anacardiaceae) extracts. Afr. J. Trad. CAM., 2(2):153-165.

Caraballo, A., Caraballo, B., RodriguezAcosta, A. 2004.Preliminary assessment of medicinal plants used as antimalarials in the south-eastern Venezuelan Amazon. Rev Soc. Bras. Med. Trop., 37(2): 186-188.

Corthout, J., Pieters, L., Claeys, M., Vanden Berghe, D.A. Viletinck, A.J. 1994. Antibacterial and molluscicidal phenolic acid from Spondias mombin. Planta Medica, 60:460-463.

Diby, Y. B., Koné, M., Yapo, A. P. 2012.Potentiel pharmacologique des écorces de tige de Spondias mombin L. (Anacardiaceae) sur la motricité in vitro du duodénum de lapin ; une plante médicinale utilisée dans le traitement traditionnel des troubles digestifs. Phytothérapie, 10:306 - 312.

Fabbrini, E., Sullivan, S., Klein, S. 2010. Obesity and nonalcoholic fatty liver disease: biochemical, metabolic, and clinical implications. Hepatol. Res., 51:679-689.

Fenneteau, M.O., Hurtaud-Roux, F., Schlegel, N. 2006.Aspect cytologique normal et pathologique du sang chez le nouveauné et le jeune enfant. Ann. Biol. Clin.,64 (1) : 17-36.

Fossat, C. and Roméo, M., 2006.Schizocytes : recherche et interprétation. Spectra Biologie $\mathrm{n}^{\circ} 150$ - 41p.

Fromenty, B. and Pessayre D. 1995. Inhibition of mitochondrial betaoxidation as a mechanism of hepatotoxicity. Pharmacol. Ther., 67:101-154.

Gbogbo, M., Koné, M., Bléyéré, N.M., Yao, K.E., Yapo, A.P. 2014. Effect of total aqueous stem bark extract of Spondias mombin L. on some biochemical and anthropometric parameters in wistar albino rats. Int. J. of Biosci.,4 (7) : 1-8.

Gomé, B.M., Kouakou, K., Touré, A., Traoré, F. 2011. Etude de la toxicité aiguë et subchronique de l'extrait aqueux de Passiflora foetida Linn. (Passifloraceae) chez les rats et les souris. Int. J. biol. Chem. Sci., 5 (5): 1777 - 1789.

Gros, M., Vrhovec, S., Brumen, M., Svetina, S., et Zeks, B. 1996.Low $\mathrm{pH}$ induced shape changes and vesiculation of human erythrocytes. General physiology and biophysics, 15(2):145163.

Guédé-Guina, F., Vangah-Manda, M., Harouna, D., Bahi, C. 1993.Potencies of Misca, a plant source concentrate against fungi. J. Ethnopharmacol. 14: 45-53.

Guo-Xiang, L. and Zai-Qun, L. 2008.The protective effects of ginsenosides on human erythrocytes against hemininduced hemolysis. Food and Chemical Toxicology, 46: 886-892.

Hayelom, K., Mekbeb, A., Eyasu, M., Wondwossen, E., Kelbesa, U. 2012. Methanolic effect of Clerodendrum myricoides root extract on blood, liver and kidney tissues of mice.Afr. Health Sci., (4): 489 - 497.

Hould, R. 1984. Technique d'histopathologie et de cytopathologie. Maloine édit. Paris, 399P.

Kessy, J. F. 1998. Conservation and utilisation of natural resources in the east Usambara convention views and local perspectives; 168pp.

Kraus, A.L. 1980. Research methodology- In Baker H.J., Lindsey,J.R., Weisbroth, S. H. - The Laboratory Rat - Academic Press, 2: 5-19.

Mebratu, A., Yamrot, K., Eyasu, M., Yonas, B., Kelbesa, U. 2013. Toxic effects of aqueous leaf extract of Vernonia 
bipontini Vatke on blood, liver and kidney tissues of mice. Mom. Eth. J. Sci., 5(2): 15-31.

Nortier, J., Depierreux, M., Vanherweghem, J.L. 1999. Phytothérapie et néphrotoxicité. Rev. Med. Brux., 1: 914.

Olson, H., Betton, G., Robinson, D., Thomas, K., Monro, A., Kolaja, G., Lilly, P., Sanders, J., Sipes, G., Bracken, W., Dorato, M., Van, D. K., Smith, P., Berger, B., Heller, A.2000. Concordance of the Toxicity of Pharmaceuticals in Humans and in Animals. Regulatory Toxicology and Pharmacol.,32:56-67.

OMS, 2002. Stratégie de l'OMS pour la médecine traditionnelle pour 20022005. Genève, WHO/ EDM/
TRM/2002.1: $65 \mathrm{p}$.

Payne, C. M., Bernstein, H., Bernstein, C., Grewal, H. 1995.Role of apoptosis in biology and pathology: resistance to apoptosis in colon carcinogenesis. Ultrastruct. Pathol., 19: 221-248.

Scoazec, J-Y. 1997. Bases fondamentales en biologie. Hépato-Gastro., 4 (1) : 45-57

Silbernagl, S., and Despopulos A. 2000. Atlas de poche de physiologie. Edition Flammarion Médecine - Sciences. Paris - France. 446p.

Yakuba, M.T., Akanji, M.A., Oladiji, A.T. 2008. Effect of oral administration of aqueous extract of Fadogia agretis stem on some testicular function indices of male rats. J. Ethanopharmacol., 111: 288-292.

\section{How to cite this article:}

Gbogbo Moussa, Toure Alassane, Kouadio YaoEmile, Oussou N'guessan Jean-Baptiste, Kone Mama, Diby Yao Bernard and Yapo AngouéPaul. 2018. Toxicity Assessment of an Aqueous Extract of the Stem Bark of Spondias mombin (Anacardiaceae) in wistar albino rats. Int.J.Curr.Microbiol.App.Sci. 7(01): 3625-3635. doi: https://doi.org/10.20546/ijcmas.2018.701.426 